\title{
IMPLEMENTASI KURIKULUM MUATAN LOKAL DI ERA OTONOMI DAERAH MENURUT UNDANG-UNDANG SISDIKNAS NOMOR 20 TAHUN 2013 DALAM MENINGKATKAN LIFE SKILLS PESERTA DIDIK
}

\author{
Agam Supriyanta \\ Sekolah Menengah Atas Negeri 1 Cianjur \\ E-mail: agam_supriyanta@yahoo.com
}

\section{ABSTRAK}

Penelitian ini bertujuan untuk mengkaji implementasi kurikulum muatan lokal untuk meningkatkan life skill mencakup analisis mulai dari proses perencanaan, pelaksanaan, dan pengevaluasian kurikulum muatan lokal yang dilaksanakan pada satuan pendidikan di era otonomi daerah menurut UU Sisdiknas No. 20 Tahun 2013; memaparkan landasan yuridis dalam pengembangan kurikulum muatan lokal di era otonomi daerah, menginventarisir faktor-faktor yang menjadi penghambat dalam implementasi kurikulum muatan lokal dan mengetahui life skills peserta didik melalui intemalisasi dalam keterampilan peserta didik di SMA. Penelitian yuridis normatif yang bersifat kualitatif ini mengacu pada norma hukum yang terdapat dalam berbagai peraturan perundang-undangan, putusan pengadilan. Penyusunan kurikulum muatan lokal yang mendorong peserta didik menguasai life skills dilaksanakan secara bottom up yakni dimulai dengan analisis konteks, analisis potensi dan kebutuhan profil peserta didik yang diinginkan yang dilakukan oleh tim pengembang kurikulum sekolah dan dilaksanakan oleh guru mata pelajaran. Tujuan program pengembangan kurikulum muatan lokal adalah untuk memberikan bekal pengetahuan keterampilan, pembentukan sikap dan prilaku siswa, agar mereka memiliki wawasan yang luas, dan mantap tentang keadaan lingkungan dan kebutuhan masyarakat.

Kata Kunci : Lokal; Otonomi; Pembangunan; Pelajaran.

\section{ABSTRACT}

This study aims to examine how the implementation's of a local-based curriculum to improve students' life skills that covers the process of planning, implementing, and evaluating local-based curriculum is carried out in educational units, examining the impact of local curriculum development on the preservation of localized culture in the skills of leamers in high school, and find out factors that hamper development local content curriculum. The research questions of this research covered how the process of planning, implementing and evaluating local curriculum is carried out in the educational unit, what factors become obstacles in developing the local content curriculum at the level of the education unit, and whether there is an improvement of local culture-based skills on the unit education that organizes local content curricula. This research employed a qualitative research method. More specifically using a descriptive case study in order the phenomenon studied is presented in detail by involving two schools as research subjects residing in Cianjur regency. The second finding is related to the improvement of life skills shown by the students on aspects of 
attitude or personal and social skills, knowledge or academic skills and vocational skills. Level of life skill mastery for these three aspects in the level of imitation, manipulation, precision, anticulation and naturalization. The third finding showed that there was a discrepancy between the concept of local curriculum developed by the govermment with the level of implementation in schools.

\section{Keywords $\quad$ : Autonomy; Development; Lesson; Local.}

\section{A. PENDAHULUAN}

Dalam kehidupan, manusia sebagai mahluk sosial yang hidup besama-sama dan berdasarkan moral estetika, etis dan dinamis sangat bergantung pada pendidikan dan juga hukum. Namun pendidikan jika tidak di dukung oleh hukum yang mengatur sepertinya pendidikanpun akan barangsur sirna dan sulit untuk di kembangkan. Ini pentingnya untuk menulis hubungan antara keduanya (Kansil, 2014). Selanjutnya menurut UU No. 20 Tahun 2003 tentang Sistem Pendidikan Nasional, pendidikan adalah usaha sadar dan terencana untuk mewujudkan suasana belajar dan proses pembelajaran agar peserta didik secara aktif mengembangkan potensi dirinya untuk memiliki kekuatan spiritual keagamaan, pengendalian dirinya, kepribadian, kecerdasan, akhlak mulia, serta keterampilan yang diperlukan dirinya, masyarakat bangsa dan negara.

Menurut Lampiran UU No. 20 Tahun 2003 tentang Sistem Pendidikan Nasional, Pendidikan adalah proses sepanjang hayat dan perwujudan pembentukan diri secara utuh dalam pengembangan segenap potensi dalam rangka pemenuhan semua komitmen manusia sebagai individu, makhluk sosial dan sebagai makhluk Tuhan. Mendidik diartikan sebagai memberi nasihat, petunjuk, mendorong agar rajin belajar, memberi motivasi, menjelaskan sesuatu atau ceramah, melarang prilaku yang tidak baik, menganjurkan dan menguatkan perilaku yang baik, dan menilai apa yang telah dipelajari anak, itu dapat dilakukan oleh semua orang (Pidarta, 2000).

Dalam konteks Indonesia, pemerintah memberikan keleluasaan dalam pengembangan Kurikulum Tingkat Satuan Pendidikan sehingga setiap satuan pendidikan dapat mengembangkan satu buku panduan yang digunakan oleh sekolah tersebut berdasarkan hasil dari analisis kebutuhan untuk mewadahi gagasan pengembangan pendidikan berbasis kearifan dan budaya lokal. 
Kurikulum yang mewadahi diversifikasi sosio-kultur memberikan peserta didik seting pembelajaran budaya lokal mendapatkan pengalaman belajar yang utuh dan akuisisi budaya lokal kedalam kurikulum memungkinkan kompetensi sosial terinternalisasi secara optimal oleh peserta didik dan memberinya bekal kecakapan hidup untuk kelak mampu menjadi individu sekaligus warga masyarakat.

\section{B. METODE}

Penelitian ini berpijak pada pendekatan kualitatif, adalah penelitian yang mengandalkan pemerolehan datanya berdasarkan fieldnotes, interviews, consercations, photographs, recordings, dan catatan peneliti. Penelitian yuridis normatif yang bersifat kualitatif adalah penelitian yang mengacu pada norma hukum yang terdapat dalam berbagai peraturan perundang-undangan, putusan pengadilan (Ali, 2011). Penelitian ini menggunakan metode análisis yuridis kualitatif, yaitu berupa interpretasi mendalam tentang tentang bahan-bahan hukum sebagaimana lazimnya penelitian hukum normatif. Sumber data terdiri dari: 1) Data primer, yaitu data yang didapat langsung dari sumbernya; 2) Data sekunder, yaitu data yang diperoleh dari tiga (tiga) bahan, antara lain yaitu: a) Bahan Hukum Primer, b)Bahan Hukum Sekunder, dan c) Bahan Hukum Tersier.

\section{HASIL ATAU PEMBAHASAN}

Sistem Pendidikan Nasional Indonesia disusun berlandaskan kepada kebudayaan bangsa Indonesia dan berdasar pada Pancasila dan UUD 1945 sebagai kristalisasi nilai-nilai hidup bangsa Indonesia. Dalam UU No.20 Tahun 2003 pasal 1 ayat 3 dikemukakan bahwa sistem pendidikan nasional adalah keseluruhan komponen pendidikan yang saling terkait secara terpadu untuk mencapai tujuan pendidikan nasional. Standar Nasional Pendidikan adalah kriteria minimal tentang sistem pendidikan di seluruh wilayah hukum Negara Kesatuan Republik Indonesia. Berdasarkan PP Nomor 19 Tahun 2005 tentang Standar Nasional Pendidikan, yang kemudian diubah menjadi PP Nomor 32 Tahun 2013 tentang Perubahan Atas PP Nomor 19 Tahun 2005 tentang Standar Nasional Pendidiikan, 
dan diubah lagi menjadi PP Nomor 13 Tahun 2005 tentang Perubahan Kedua Atas PP Nomor 18 Tahun 2005 tentang Standar Nasional Pendidikan, disebutkan 8 (delapan) Standar Nasional Pendidikan, yakni: Standar Isi, Standar Kompetensi Lulusan, Standar Proses, Standar Penilaian, Standar Sarana Prasarana, Standar Tendik, Standar Biaya dan Standar Pengelolaan.

Undang-Undang Republik Indonesia Nomor 23 Tahun 2014 Tentang Pemerintahan Daerah telah memberikan wewenang seluas-luasnya kepada daerah untuk mengatur rumah tangganya, termasuk dalam bidang pendidikan. Hal ini memberikan peluang kepada pihak daerah untuk merumuskan dan menetapkan kurikulum yang sesuai dengan ciri khas daerah yang bersangkutan, baik segi kultural, sosial maupun ekonomi.

Substansi muatan lokal ditentukan oleh masing-masing satuan pendidikan. Pendapat ini tampaknya menganggap bahwa kurikulum muatan lokal hanya bisa diakomodasi melalui kegiatan yang terpisah dengan mata pelajaran (Murlyasa, 2009). Mata pelajaran muatan lokal harus memuat karakteristik budaya lokal, keterampilan, nilai-nilai luhur budaya setempat dan mengangkat permasalahan sosial dan lingkungan yang pada akhirnya mampu membekali siswa dengan keterampilan dasar sebagai bekal dalam kehidupan (life skill).

Tujuan muatan lokal adalah untuk mempersiapkan peserta didik agar memiliki wawasan yang luas dan mantap tentang kondisi lingkungannya, keterampilan fungsional, sikap dan nilai-nilai, bersedia melestariakan dan mengembangkan sumber daya alam, serta meningkatkan kualitas sosial dan budaya daerah sesuai dengan pembangunan daerah dan pembangunan nasional. Secara khusus tujuan muatan lokal adalah: (a) Peserta didik belajar dengan lebih mudah tentang lingkungandan kebudayaan di daerahnya serta bahan-bahan yang bersifat aplikatif dan terintegrasi dengan kehidupan nyata. (b) Peserta didik dapat memanfaatkan sumber-sumber belajar seetmpat untuk kepentingan pembelajaran di sekolah. (c) Peserta didik lebih mengenal dan akrab dengan lingkungan alam, lingkungn sosial, dan budaya yang terdapat di daeranya masing-masing. (d) Peserta dididk dapat meningkatkan pengetahuan, keterampilan, sikap dan nilainilai yang menunjang pembangunan daerahnya. (e) Peserta didik dapat 
mengembangkan materi muatan lokal yang dapat menghasilkan nilai ekonomi tinggi di daerahnya sehingga dapat hidup mandiri, menolong orang tuanya dan menolong dirinya sendiri dalam rangka memenuhi kebutuhan hidupnya. (f) Peserta didik dapat menerapakan pengetahuan dan keterampilan yang di pelajarinya untuk memecahkan masalah yang di temukandi sekitarnya. (g) Peserta didik menjadi motivasi untuk ikut melestarikan budaya dan lingkungannya serta terhindar dari keterasingan terhadap lingkungnnya sendiri (Ismawati, 2012).

Keberadaan peraturan perundangan dinilai sebagai langkah hukum yang positif untuk menciptakan kepastian program pembangunan pendidikan, namun demikian terdapat pula persoalan-persoalan yang dihadapi oleh penyelenggara pendidikan di pusat maupun di daerah. Pemerintah telah mengatur segala aturan terkait dengan penyelenggaraan sistem pendidikan nasional dalam Pasal 31 ayat (3) UUD 1945. Dalam kebijakan UUD tersebut terdapat 5 pengaruh politik terhadap pendidikan yaitu: (a) Politik berpengaruh pada aktivitas pendidikan dalam penciptaan nilai-nilai dan harapan-harapan warga negara seperti apa yang dibutuhkan oleh negara, (b) politik berpengaruh pada anggaran pendidikan, (c) politik berpengaruh terhadap sumberdaya pendidikan seperti gaji guru, sarana prasarana penunjang kegiatan belajar, dan pelatihan guru, (d) politik berpengaruh pada sistem persekolahan seperti struktur sekolah, sistem penghargaan terhadap guru, dan sistem penerimaan siswa, (e) politik berpengaruh pada mutu lulusan yang diihat dari bagaimana lulusan pendidikan berperilaku politik, berperilaku budaya, berperilaku ekonomi dan berperilaku sosial (Levin, 1976). Kemudian Pasal 18 ayat (2) dan ayat (5) Undang-Undang Dasar Negara Republik Indonesia Tahun 1945 menyatakan bahwa Pemerintahan Daerah berwenang untuk mengatur dan mengurus sendiri Urusan Pemerintahan menurut Asas Otonomi dan Tugas Pembantuan dan diberikan otonomi yang seluas-luasnya.

Kebijakan otonomi daerah bukan tanpa alasan. Dilihat dari landasan yuridis jelas telah diamanatkan oleh Ketetapan MPR no. XV/MPR/1998 tentang Penyelenggaraan Otonomi Daerah, Pengaturan dan pemanfaatan Sumber Daya Nasional yang Berkeadilan serta Perimbangan Keuangan Pusat dan Daerah dalarn Kerangka Negara Kesatuan Republik Indonesia. Ketetapan MPR tersebut 
kemudian ditindaklanjuti dengan dikeluarkannya UndangUndang Nomor 23 tahun 2014 tentang Pemerintahan Daerah dan Undang-Undang nomor 33 tahun 2004 tentang Perimbangan Keuangan antara Pusat dan Pemerintahan Daerah. Prinsip otonomi daerah adalah pemerintahan daerah diberi wewenang untuk mengelola daerahnya sendiri. Hanya saja ada beberapa bidang yang tetap ditangani pemerintah pusat, yaitu agama, peradilan, pertahanan, dan keamanan, moneter/fiscal, politik luar negeri dan dalam negeri serta sejumlah kewenangan bidang lain (meliputi perencanaan nasional dan pengendalian pembangunan secara makro, dana perimbangan keuangan, sistem administrasi Negara dan lembaga perekonomian Negara, pembinaan sumber daya manusia, pendayagunaan sumber daya alam serta teknologi tinggi yang strategis, dan konversi serta standarisasi nasional). Sumber daya alam daerah di Indoinesia yang tidak merata juga merupakan salah satu penyebab diperlukannya suatu sistem pemerintahan yang memudahkan pengelolaan sumber daya alam yang merupakan sumber pendapatan daerah sekaligus menjadipendapatan nasional. Sebab seperti yang kita ketahui bahwa terdapat beberapa daerah yang pembangunannya memang harus lebih cepat daripada daerah lain. Karena itulah pemerintah pusat membuat suatu sistem pengelolaan pemerintahan di tingkat daerah yang disebut otonomi daerah.

Pada Tanggal 30 September 2014, Presiden Republik Indonesia telah menandatangani Undang-Undang No. 23 Tahun 2014 tentang Pemerintahan Daerah, menggantikan Undang-Undang No. 32 Tahun 2004, yang dianggap sudah tidak sesuai lagi dengan perkembangan keadaan, ketatanegaraan, dan tuntutan penyelenggaraan pemerintahan daerah.

Dalam Bab IV Pasal 9 ayat 1 menyebutkan bahwa: "Urusan Pemerintahan terdiri atas urusan pemerintahan absolut, urusan pemerintahan konkuren, dan urusan pemerintahan umum”. Urusan pemerintahan absolut yaitu urusan pemerintahan yang sepenuhnya menjadi kewenangan pemerintah pusat. Sedangkan urusan pemerintahan konkuren adalah urusan pemerintahan yang dibagi antara pemerintah pusat dengan pemerintahan daerah provinsi/ kabupaten/kota, yang sekaligus juga menjadi dasar bagi pelaksanaan Otonomi Daerah. Sementara, urusan pemerintahan umum adalah urusan pemerintahan yang 
menjadi kewenangan Presiden sebagai kepala pemerintahan. Urusan pemerintahan konkuren adalah urusan pemerintahan yang berbagi antara Pemerintah Pusat, Pemerintah Provinsi dan Pemerintah Kabupaten/Kota.

Berlakunya otonomi daerah, maka dalam bidang pendidikan aspe-aspek yang berkaitan dengan penyelenggaraan pembangunan di bidang ini juga mengalami perubahan. Perubahannya antara lain, berkurangnya peran pemerintah pusat. Dengan kata lain dapat dinyatakan bahwa telah terjadi perubahan penyelenggaraan pendidikan dari sentralistis ke arah desentralistis. Konsep desentralisasi pendidikan itu sendiri adalah konsep yang relatif baru untuk di Indonesia. Sehingga pada saat ini, salah satu tantangan yang paling penting adalah tersusunnya kebijakan untuk mendelegasikan wewenang operasional pemerintah pusat ke daerah, khususnya bidang pendidikan. Desentralisasi pendidikan merupakan upaya memindahkan tugas dan tanggung jawab penyelenggaraan pendidikan yang semula terpusat (sentralistik) menjadi pendidikan yang berbasis kepentingan daerah atau masyarakat. Titik berat pelaksanaan desentralisasi pendidikan adalah lebih mengutamakan pada peningkatan peran dan partisipasi daerah termasuk masyarakat dalam rangka terselenggaranya pendidikan seperti apa yang diinginkan untuk dilaksanakan di daerah. Sehingga desentralisasi pendidikan menghasilkan otonomi (Djohar, 2003).

Penetapan tujuan menjadi sangat penting dalam menentukan keberhasilan implementasi sebuah kurikulum. Berdasarkan penelitian yang dilakukan oleh Wahyudin (2017) terkait dengan kurikulum lokal menyebutkan bahwa terdapat ketidaksesuaian antara kebijakan kurikulum dengan implementasi yang diterapkan di sekolah. Selain itu, Wahyudin (2016) menegaskan bahwa kurikulum yang telah siap dikembangkan pada tataran konsep, ketika diterapkan di sekolah, sekolah belum siap melaksanakan setiap konsep tersebut. Kedua hal ini mengindikasikan bahwa implementasi sebuah kurikulum merupakan hal pelik yang memerlukan kajian matang sebelum dijadikan kebijakan suatu sekolah untuk dilaksanakan.

Kecakapan hidup sebagai pengalih bahasaan dari life skills merupakan penguasaan keterampilan yang terkait dengan kebutuhan kehidupan sehari-hari yang harus dikuasai peserta didik. Pendidikan kecakapan hidup dikelompokkan 
berbeda-beda oleh ahli yang berbeda. 10 jenis keterampilan hidup yang penting dikuasai oleh peserta didik menurut WHO : 1) Fokus dan control diri, 2) Pengambilan perspektif, 3) Berkomunikasi, 4) Membangun koneksi, 5) Berpikir kritis, 6) Menghadapi tantangan, 7) Hubungan interpersonal, 8) Empati, 9) Mengatasi stress, 10) Menangani emosi.

Pengelompokkan jenis kecakapan hidup menjadi dua menjadi dua jenis kecakapan, ${ }^{1}$ yaitu :

1. Kecakapan umum atau general life skills mencakup kecakapan mengenali diri sendiri atau pada istilah Broling disebut social/personal skills, kecakapan berpikir rasional atau thinking skill dan kecakapan social.

2. Kecakapan khusus, meliputi kecakapan akademi atau kemampuan berpikir ilmiah, dan kecakapan vokasional.

Kurikulum yang memuat kecakapan hidup sangat berguna bagi peserta didik, manfaat yang diperoleh dengan adanya integrase dalam pembelajaran baik secara intrakurikuler ataupun ekstrakurikuler menentukan masa sekolah dan setelah sekolah.

Pada pelaksanaannya, Muatan Lokal dapat menjadi pelajaran tersendiri, dipadukan dengan mata pelajaran lain atau 'integrasi', atau melalui kegiatan pengembangan diri yang dapat memberikan bekal sikap, pengetahuan, dan keterampilan kepada peserta didik agar:

1. Mengenal dan menjadi lebih akrab dengan lingkungan alam, sosial, dan budayanya;

2. Memiliki bekal kemampuan dan keterampilan serta pengetahuan mengenai daerahnya yang berguna bagi dirinya maupun lingkungan masyarakat pada umumnya; dan

3. Memiliki sikap dan perilaku yang selaras dengan nilai-nilai/aturan-aturan yang berlaku di daerahnya, serta melestarikan dan mengembangkan nilainilai luhur budaya setempat dalam rangka menunjang pembangunan nasional.

1 Rusman, M. Manajemen Kurikulum, Jakarta: Rajawali Pers, 2012, hlm. 29. 
Pasal 77 Peraturan Pemerintah Nomor 32 Tahun 2013 tentang Perubahan atas Peraturan Pemerintah Nomor 19 Tahun 2005 tentang Standar Nasional Pendidikan menyatakan bahwa muatan lokal untuk setiap satuan pendidikan berisi muatan dan proses pembelajaran tentang potensi dan keunikan lokal, muatan lokal tersebut dikembangkan dan dilaksanakan pada setiap satuan pendidikan.

Pengembangan muatan lokal dapat dibangun melalui dua strategi: (1) Satuan pendidikan menentukan jenis muatan lokal berdasarkan hasil analisis potensi daerah dan potensi satuan pendidikan; dan (2) Pemerintah daerah membuat kebijakan tentang muatan lokal yang diselenggarakan di daerahnya, berdasarkan hasil analisis yang diperoleh dari jenis muatan lokal yang diselenggarakan pada satuan-satuan pendidikan di daerahnya.

Berikut digambarkan dua strategi pengembangan muatan lokal:

1. Dari bawah ke atas (bottom up)

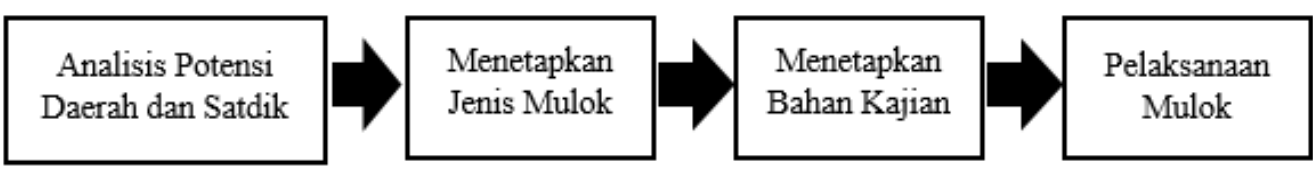

Gambar 1. Alur pengembangan muatan lokal dari bawah ke atas

Gambar di atas menjelaskan alur pengembangan muatan lokal yang dibangun secara bertahap dan tumbuh pada satuan pendidikan. Hal ini menunjukkan bahwa satuan pendidikan mempunyai kewenangan untuk menentukan sendiri jenis muatan lokal yang akan dilaksanakan sesuai dengan hasil analisis konteks identifikasi kebutuhan dan ketersediaan sumber daya pendukung. Penentuan jenis muatan lokal kemudian diikuti dengan penyusunan kurikulum yang sesuai.

2. Dari atas ke bawah (top down)

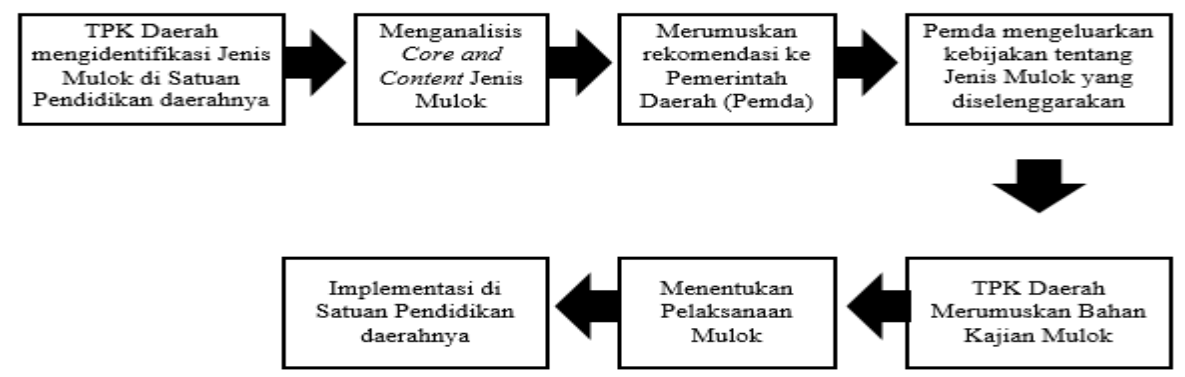

Gambar 2. Alur pengembangan muatan lokal dari atas ke bawah 
Gambar di atas menjelaskan alur pengembangan muatan lokal dimana pemerintah daerah sudah memiliki bahan kajian muatan lokal yang diidentifikasi dari jenis muatan lokal yang diselenggarakan oleh satuan-satuan pendidikan di daerahnya. Tim pengembang muatan lokal mengidentifikasi dan menganalisis core and content dari jenis muatan lokal secara keseluruhan. Setelah core and content umum ditemukan, maka tim pengembang kurikulum daerah merumuskan rekomendasi kepada pemerintah daerah untuk membuat kebijakan tentang jenis muatan lokal yang akan diselenggarakan di daerahnya.

Selain itu sebelum menetapkan muatan lokal, satuan pendidikan perlu melakukan serangkaian kegiatan agar muatan lokal yang dikembangkan benar-benar realistis dan implementatif sesuai dengan kebutuhan peserta didik terhadap pengembangan potensi di daerah tempat tinggalnya. Langkah awal penentuan muatan lokal, meliputi (1) identifikasi dan analisis muatan lokal, (2) menentukan jenis muatan lokal, dan (3) menentukan bahan kajian muatan lokal.

Penentuan dan pelaksanaan muatan lokal dapat digambarkan sebagai berikut:

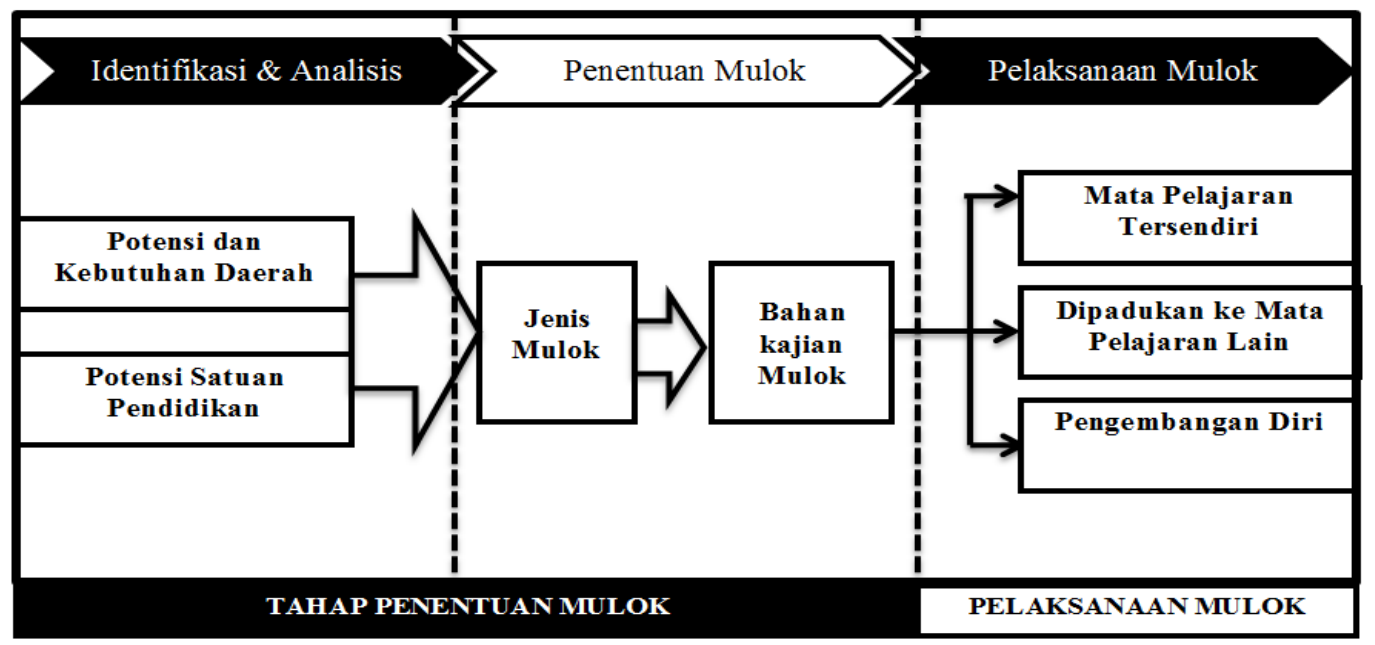

Gambar 3. Alur tahap penentuan dan pelaksanaan muatan lokal

Pelaksanaan muatan lokal melalui mata pelajaran tersendiri dapat digambarkan sebagai berikut: 


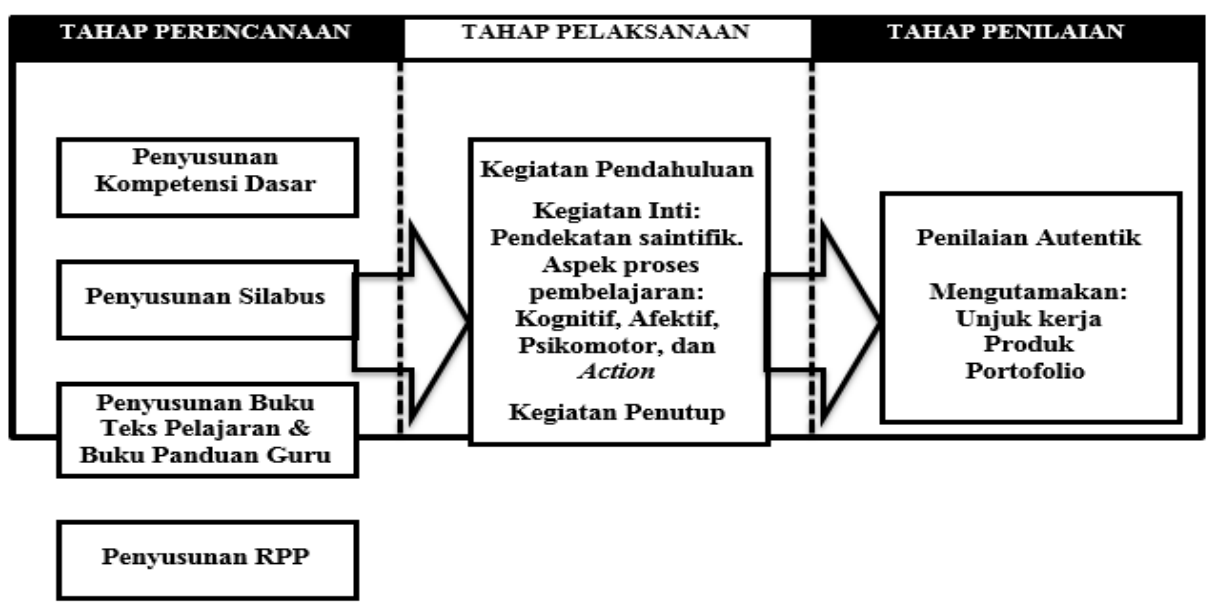

Gambar 4. Pelaksanaan muatan lokal melalui mata pelajaran

Pelaksanaan muatan lokal dipadukan ke dalam mata pelajaran lain dapat digambarkan sebagai berikut:

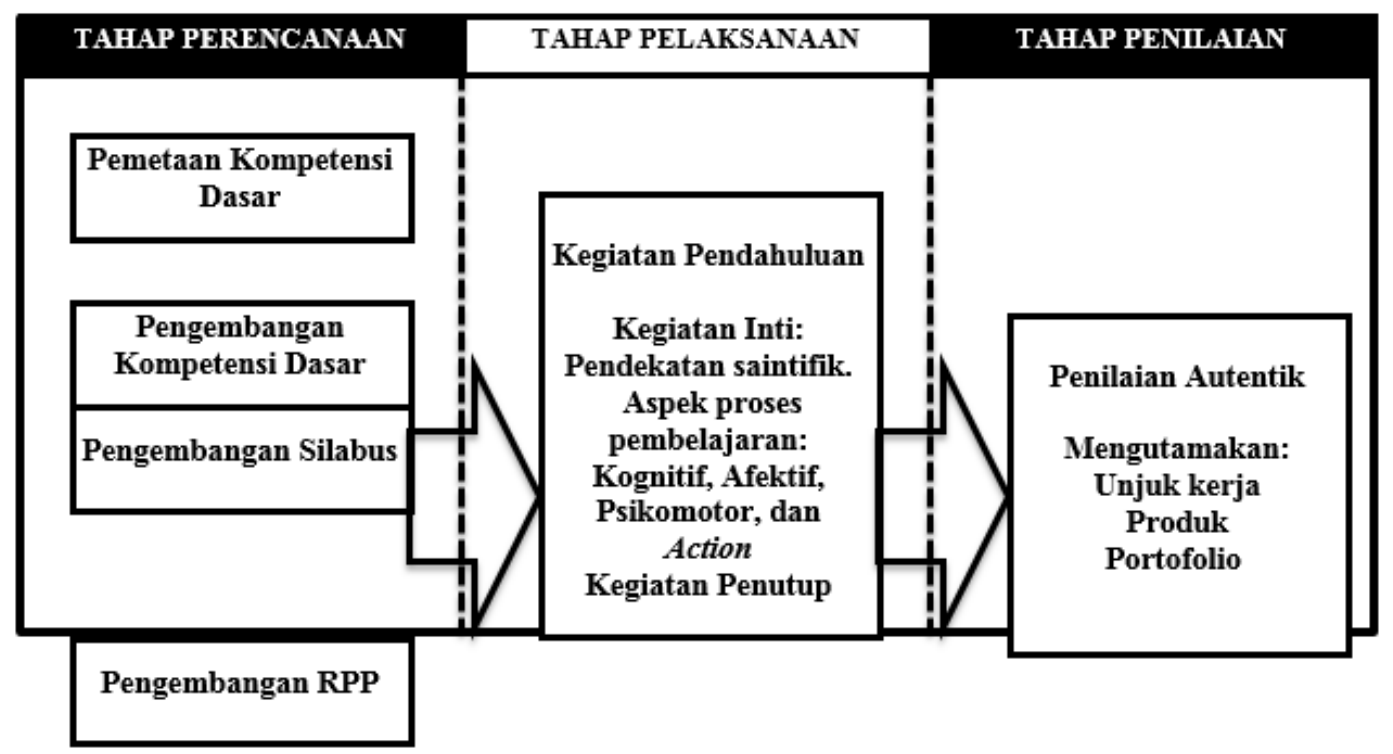

Pengembangan Bahan
Ajar

Gambar 5. Alur pelaksanaan muatan lokal dipadukan ke dalam mata pelajaran lain.

Pelaksanaan muatan lokal melalui program ekstrakurikuler dapat digambarkan sebagai berikut: 


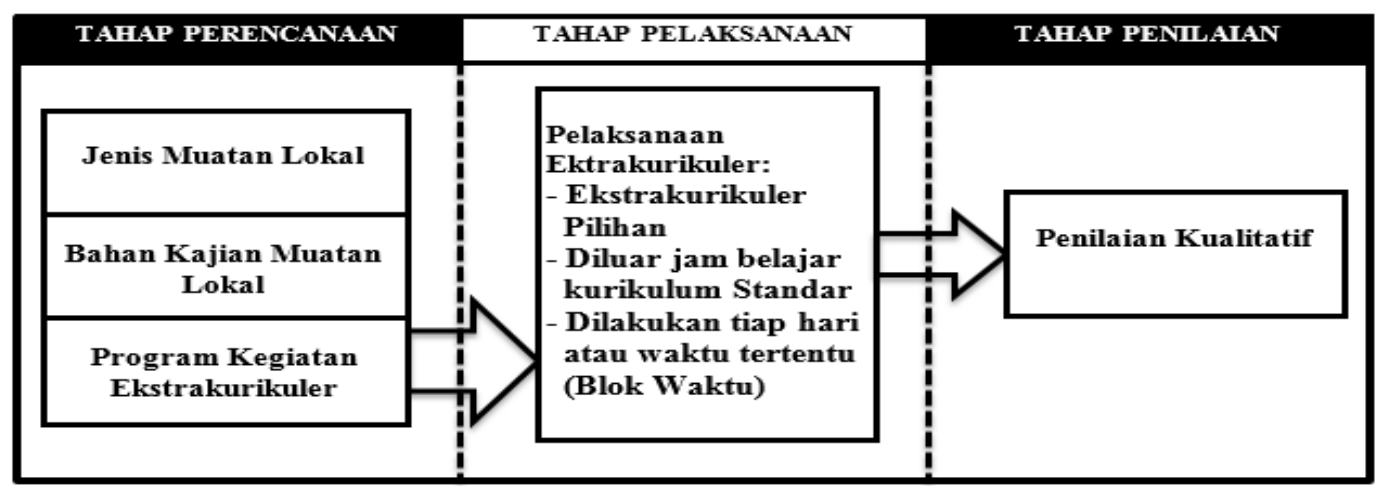

Gambar 6. Alur pelaksanaan muatan lokal melalui program ekstrakurikuler

\section{PENUTUP}

Kurikulum muatan lokal merupakan bagian yang tidak terpisahkan dari kurikulum nasional, keberadaannya lebih diutamakan agar penyelenggaraan pendidikan di daerah lebih meningkat relevansinya dengan keadaan dan kebutuhan lingkungannya, yang ditujukan terutama agar peserta didik mencintai lingkungannya. Hal tersebut sejalan dengan upaya peningkatan mutu pendidikan nasional, oleh karena itu keberadaan kurikulum muatan lokal harus mendukung pelaksanaan kurikulum nasional. Penyusunan kurikulum muatan lokal yang mendorong peserta didik menguasai life skills dilaksanakan secara bottom up yakni dimulai dengan analisis konteks, analisis potensi dan kebutuhan profil peserta didik yang diinginkan yang dilakukan oleh tim pengembang kurikulum sekolah dan dilaksanakan oleh guru mata pelajaran. Lebih spesifik, guru mengembangkan pengembangan kompetensi dasar yang kemudian dilaksanakan secara intra kurikuler dan ekstra kurikuler sehingga membantu peserta didik memperoleh kecakapan hidup umum dan khusus (general and spesicif life skills).

Tujuan program pengembangan kurikulum muatan lokal adalah untuk memberikan bekal pengetahuan keterampilan, pembentukan sikap dan prilaku siswa, agar mereka memiliki wawasan yang luas, dan mantap tentang keadaan lingkungan dan kebutuhan masyarakat. Sehingga nanti siswa mampu mengembangkan serta melestarikan sumber daya alam dan kebudayaan yang mendukung pembangunan nasional dan daerah. Implementasi kurikulum muatan lokal yang memiliki soko kegiatan penguasaan life skills dilakukan melalui tiga 
cara. Pertama melalui mata pelajaran berdiri sendiri yakni bahasa Sunda dan PKWU sehingga peserta didik meningkat penguasaan kecakapan sosial dan vokasionalnya (social skill and vocational skill). Kedua dilaksanakan dengan cara terintegrasi ke dalam mata pelajaran pada materi ajar tertentu, dan ketiga menjadi kegiatan ekstrakurikuler.

Pengembangan kurikulum muatan lokal yang menunjang pada penguasaan life skills yang dipandang sebagai muatan baru pada kurikulum menghadapi kendala dalam pengembangan, implementasi dan evaluasi hasil. Hal-hal yang diasumsikan menjadi faktor penghambat diuraikan berikut ini: (a) sekolah sebagai institusi tidak percaya diri untuk mengembangkan kurikulum muatan lokal terkait cakupan life skills dan kompetensi kognitif-psikomotor yang dapat dikembangkan.

\section{DAFTAR PUSTAKA}

Ali, Z. (2011). Metode Penelitian Hukum (3rd ed.). Sinar Grafika.

Djohar. (2003). Pendidikan Strategik Alternatif untuk Pendidikan Masa Depan. LESFI. Ismawati, E. (2012). Telaah Kurikulum dan Pengembangan Bahan Ajar. Yayasan Obak. Kansil. (2014). Pengantar Ilmu Hukum dan Tata Hukum Indonesia. Balai Pustaka.

Levin, M. C. and H. M. (1976). The Limits Of Educational Reform. David Mekay Compani, INC.

Murlyasa, E. (2009). Implementasi Kurikulum Tingkat Satuan Pendidikan Kemandirian guru dan Kepala Sekolah (3rd ed.). PT Bumi Aksara.

Pidarta, M. (2000). Landasan Kependidikan. Rineka Cipta. 